\title{
HUBUNGAN PERSEPSI DAN TINGKAT KEAKTIFAN DENGAN HASIL BELAJAR MAHASISWA BIOLOGI PADA PERKULIAHAN BIOTEKNOLOGI DI UNIVERSITAS MUHAMMADIYAH MALANG
}

\author{
Akhmad Sukri ${ }^{1}$ dan Elly Purwanti ${ }^{2}$ \\ ${ }^{1}$ Jurusan Biologi, IKIP Mataram \\ e-mail: sukri_bio04@yahoo.co.id \\ ${ }^{2}$ Jurusan Biologi, Universitas Muhammadiyah Malang
}

\begin{abstract}
ABSTRAK
Ada tiga faktor yang mempengaruhi hasil belajar siswa yaitu (1) sumber belajar dan proses belajar di sekolah, (2) kemampuan dan kecakapan guru, dan (3) kemampuan peserta didik. Dosen melalui empat pilar kompetensi dituntut untuk mendorong dan memotivasi mahasiswa dalam belajar. Hal ini dilakukan untuk meningkatkan keaktifan mahasiswa dalam belajar, sehingga dapat meningkatkan hasil belajar. Penelitian ini mengungkap hubungan persepsi dan tingkat keaktifan dengan hasil belajar mahasiswa biologi pada perkuliahan bioteknologi di Universitas Muhammadiyah Malang. Hasil penelitian menunjukkan ada korelasi yang signifikan antara tingkat keaktifan mahasiswa dengan hasil belajar bioteknologi $(r=0,789)$, sedangkan persepsi mahasiswa tidak memiliki korelasi dengan hasil belajar bioteknologi $(r=0,00)$.
\end{abstract}

Kata Kunci: Persepsi, hasil belajar, bioteknologi

\section{PENDAHULUAN}

Proses pembelajaran merupakan suatupembelajaran yang berpusat pada guru kegiatan formal yang ada pada lembagamenjadi student center, yaitu pembelajaran pendidikan terutama di sekolah. Dalam prosesyang berpusat pada siswa. Kecakapan guru ini pembelajaran terjadi interaksi antara pendidiksangat penting, karena bagaimanapun bagus dan peserta didik, yaitu pendidik yangdan idealnya kurikulum pendidikan tanpa mengajar dan perserta didik yang belajardiimbangi kemampuan guru atau dosen dalam (Syah, 2004). Proses pembelajaran akanmengimplementasikannya, maka semuanya mempengaruhi hasil belajar yang diperolehkurang bermakna (Sanjaya, 2006).

siswa. Hal ini sesuai dengan yang diungkapkan oleh Sciefelbein dan Simon (1981), bahwa ada tiga faktor yang mempengaruhi hasil belajar siswa yaitu, 1) sumber belajar dan proses belajar di sekolah, 2) kemampuan dan kecakapan guru, dan 3) kemampuan peserta didik.

Faktor lain yang mempengaruhi hasil belajar selain proses pembelajaran adalah kecakapan guru. Guru memegang peranan penting dalam proses pembelajaran di kelas. Guru bertindak sebagai mediator yang mengarahkan peserta didik dalam belajar. Hal ini karena paradigma pembelajaran telah berubah dari teacher center, yaitu Guru sebagai seorang mediator dituntut untuk menguasai empat kompetensi, yaitu 1) kompetensi pedagogik, 2) kompetensi kepribadian, 3) kompetensi sosial, dan 4) kompetensi profesional. Kompetensi profesional menuntut guru untuk menguasai materi, bagaimana menyampaikan materi dengan baik, dan semua seluk beluk yang berkaitan dengan pembelajaran. Diharapkan dengan penguasaan kompetensi profesional dapat membangkitkan minat dan motivasi siswa 
dalam belajar, sehingga
meningkatkan hasil belajar siswa

Dalam meningkatkan kualitas kompetensi profesional, guru dapat melakukan self assessment dalam setiap pembelajaran yang dilakukan dan memperhatikan serta mengambil masukanmasukan atas tanggapan siswa terkait dengan pembelajaran yang dilakukan. Tidak banyak guru yang sering melakukan self asssessment dalam setiap pembelajarannya, apalagi mengambil feedback dari siswa terkait pembelajaran, padahal feedback dari siswa sangat penting untuk perbaikan proses pembelajaran. Hal ini juga berlaku untuk dosen, karena peran dan fungsi guru dan dosen dalam pembelajaran adalah sama.

Guru maupun dosen melalui empat pilar kompetensi yang harus dikuasainya juga dutuntut untuk mendorong dan memotivasi siswa atau mahasiswa dalam belajar. Hal ini dilakukan untuk dapat meningkatkan keaktifan mahasiswa dalam belajar, sehingga pada akhirnya dapat meningkatkan hasil belajar siswa atau mahasiswa.

Penelitian ini mengungkap bagaimana hubungan tanggapan atau persepsi dan tingkat keaktifan dengan hasil belajar mahasiswa biologi pada perkuliahan bioteknologi di Universitas Muhammadiyah Malang.

\section{METODE PENELITIAN}

Penelitian ini adalah penelitian korelasional melalui pendekatan deskriptif yang melihat hubungan persepsi mahasiswa dengan hasil belajar bioteknologi pada perkuliahan bioteknologi di Universitas Muhammadiyah Malang. Objek dalam penelitian ini adalah seluruh mahasiswa bioteknologi semester genap tahun 2012/2013 yang berjumlah 119 orang. Data diambil menggunakan angket yang berisi tanggapan mahasiswa terhadap perkuliahan bioteknologi. Angket berisi lima pertanyaan yang menyangkut; perasaan mengikuti perkuliahan bioteknologi, ketertarikan mahasiswa terhadap perkuliahan bioteknologi, penguasaan materi oleh mahasiswa, tingkat kesulitan materi bioteknologi yang disampaikan oleh dosen, dan tanggapan mahasiswa terhadap penyampaian materi oleh dosen.

Data tingkat keaktifan diambil dari formulir penilaian asesmen autentik yang telah disusun, kemudian dirubah menjadi skala interval. Penilaian asesmen autentik meliputi empat kegiatan yaitu keterampilan bertanya, kemampuan mengajukan pendapat, tampilan presentasi, dan keterampilan menyampaikan ide atau berdebat. Format penilaian asesmen autentik mengikuti kaedah sebagai berikut: skor $1=$ rendah, $2=$ cukup, $3=$ baik, dan 4 = sangat baik.

Data hasil belajar mahasiswa diperoleh dari nilai akhir yang merupakan akumulasi dari nilai kuis, nilai tugas, nilau ujian midle semester dan nilai ujian semester yang dihitung berdasarkan penilaian acuan normal (PAN).

Teknik analisis data hasil penelitian dilakukan menggunakan analisis statistik deskriptif dan analisis korelasi product moment Pearson. Analisis data dilakukan dengan bantuan perangkat komputer SPSS 16 for Windows.

\section{HASIL PENELITIAN DAN PEMBAHASAN}

\section{Hasil Penelitian}

\section{a. Hasil Analisis Angket Persepsi Mahasiswa Terhadap Perkuliahan Bioteknologi}

Berdasarkan analisis angket persepsi mahasiswa terhadap perkuliahan bioteknologi, diperoleh tanggapan yang beragaram terkait pembelajaran bioteknologi. Gambar 1-5 menampilkan persentase tanggapan mahasiswa terkait pernyataan-pernyataan yang diajukan. 
Gambar 1. Grafik Tanggapan Mahasiswa tentang

Perasaaan Mengikuti Perkuliahan Bioteknologi

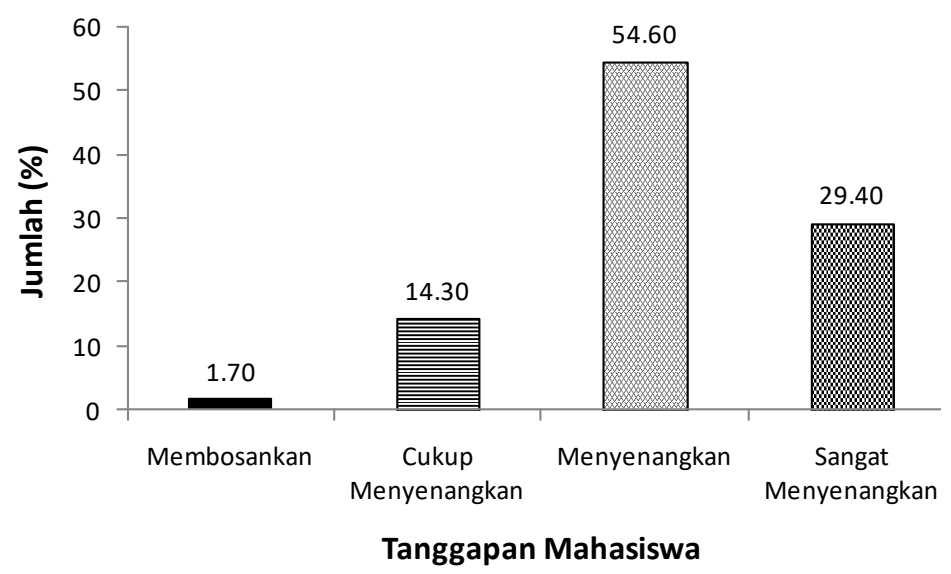

Gambar 2. Grafik Ketertarikan Mahasiswa Terkait

Penyampaian Materi Bioteknologi oleh Dosen

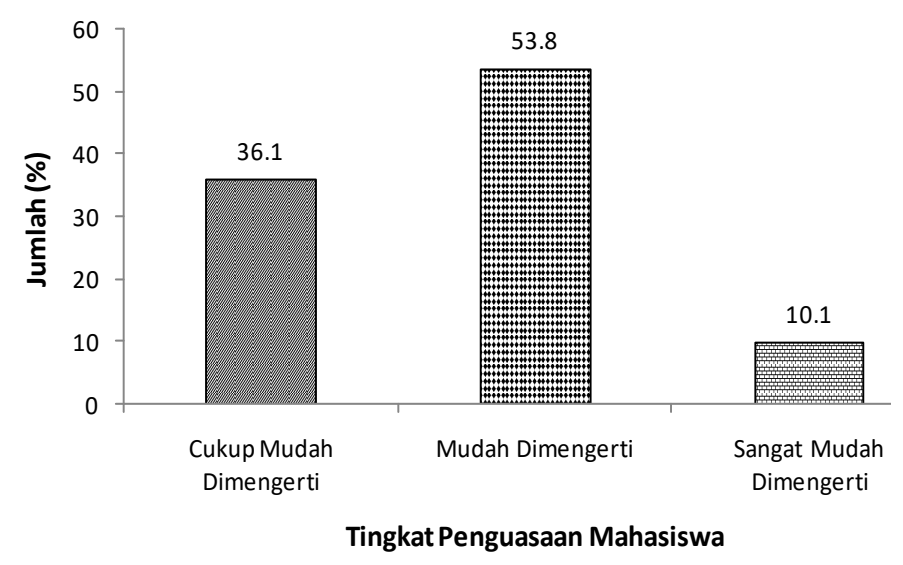

Gambar 3. Grafik Tingkat Penguasaan Mahasiswa Terkait Penyampaian Materi Bioteknologi oleh Dosen.

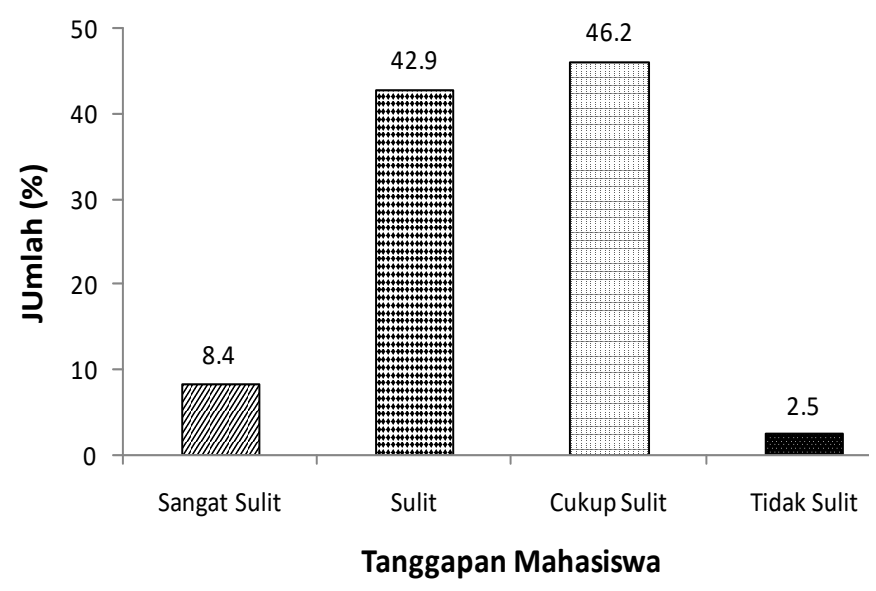




\section{Gambar 4. Grafik Tanggapan Mahasiswa Terkait} Tingkat Kesulitan Materi Bioteknologi

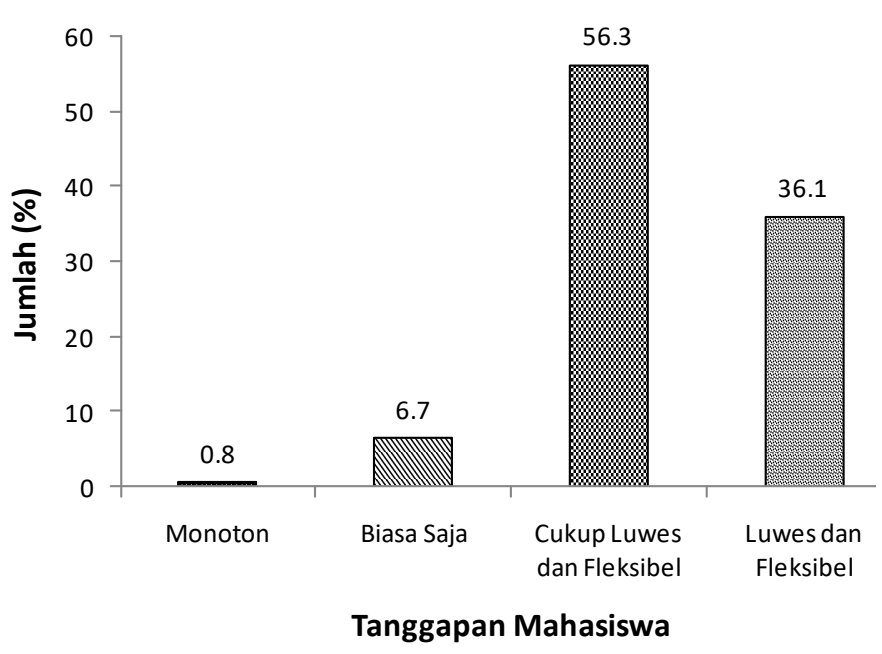

Gambar 5. Grafik Tanggapan Mahasiswa Terkait Kreatifitas Penyampaian Materi Bioteknologi oleh Dosen

\section{b. Hasil Analisis Uji Korelasi Product Moment Pearson}

Hasil analisis korelasi antara persepsi mahasiswa dan tingkat keaktifan terhadap perkuliahan bioteknologi dengan hasil belajar mahasiswa ditampilkan pada Tabel 1.

\section{Pembahasan}

Hasil analisis angket persepsi
mahasiswa terhadap perkuliahan
bioteknologi menunjukkan persepsi yang
beragam. Grafik tanggapan mahasiswa
terhadap perasaan mengikuti perkuliahan
bioteknologi menunjukkan $54,60 \%$
mahasiswa merasa senang belajar
bioteknologi, sedangkan yang merasa
sangat senang sebesar $29,40 \%$. Namun,
tidak seluruh mahasiswa merasa senang
dalam belajar, 1,70\% mahasiswa merasa
membosankan belajar bioteknologi, dan
$14,30 \%$ merasa cukup menyenangkan
(Gambar 1). Secara umum, mahasiswa
merasa senang untuk belajar bioteknologi.

Tanggapan mahasiswa terhadap perkuliahan bioteknologi dilanjutkan dengan pertanyaan untuk mengetahui ketertarikan mahasiswa terhadap materi bioteknologi. Hal ini dilakukan sebagai cross check tanggapan mahasiswa terhadap perasaan mengikuti perkuliahan bioteknologi, karena biasanya apabila seseorang sudah merasa senang tentu akan tertarik untuk belajar atau sebaliknya.

Grafik tanggapan mahasiswa terhadap materi yang disampaikan oleh dosen menunjukkan sebagian besar mahasiswa menganggap materi bioteknologi menarik (Gambar 2). Sebesar $24,4 \%$ mahasiswa menganggap materi bioteknologi sangat menarik, 52,9\% menjawab menarik, $21 \%$ berpendapat cukup menarik, dan 1,7\% mahasiswa menganggap materi bioteknologi tidak menarik. Hasil ini berbanding linier dengan hasil yang diperoleh mengenai tanggapan mahasiswa terhadap perasaan mengikuti perkuliahan bioteknologi. Karena jumlah mahasiswa yang menyatakan pembelajaran bioteknologi menyenangkan hampir sama dengan 
jumlah mahasiswa yang menyatakan materi bioteknologi menarik.

Grafik tanggapan mahasiswa terkait tingkat penguasaan mahasiwa terhadap materi yang disampaikan oleh dosen sejalan dengan tingkat kesenangan dan ketertarikan mahasiswa terhadap bioteknologi. Hal ini dapat diamati pada jumlah mahasiswa yang menyatakan materi bioteknologi yang disampaikan oleh dosen mudah dimengerti sebesar $53,8 \%$, bahkan sebesar $10,1 \%$ mahasiswa menyatakan sangat mudah dimengerti dan $36,1 \%$ menyatakan cukup mudah dimengerti. Hal ini mengindikasikan bahwa peran dosen dalam pembelajaran untuk membuat mahasiswa memahami dan mengerti materi perkuliahan sangat diperlukan sebagai implementasi empat pilar kompetensi dosen. Hasil ini juga menunjukkan bahwa dosen sudah cukup berhasil dalam pembelajaran bioteknologi untuk dapat membuat mahasiswa paham dan mengerti materi perkuliahan, namun hasil ini perlu diperkuat dengan melihat hasil belajar mahasiswa.

Tanggapan mahasiswa terkait pernyataan tingkat kesulitan materi bioteknologi menunjukkan sebesar $8,4 \%$ mahasiswa merasa materi bioteknologi sangat sulit, $42,9 \%$ merasa sulit, $46,2 \%$ merasa cukup sulit, dan hanya $2,5 \%$ mahasiswa merasa tidak sulit (Gambar 4). Hal ini dapat dipahami karena bioteknologi menuntut mahasiswa untuk memahami dan mengerti berbagai bidang ilmu yang menjadi fondasi bioteknologi seperti genetika dan mikrobiologi.

\section{Tabel 1 Tabulasi Hasil Uji Korelasi antara Persepsi Mahasiswa dan} Tingkat Keaktifan terhadap Hasil Belajar

\begin{tabular}{|ll|r|r|r|}
\hline \multicolumn{2}{|c|}{ Correlations } \\
\hline Hasil_Belajar & Pearson Correlation & Hasil_Belajar & $\begin{array}{c}\text { Tingkat_ } \\
\text { Keaktifan }\end{array}$ & $\begin{array}{c}\text { Persepsi_. } \\
\text { Mahasiswa }\end{array}$ \\
& Sig. (2-tailed) & 1 & $.789 "$ & .000 \\
& N & 119 & .000 & .999 \\
& Pearson Correlation & $.789 "$ & 119 & 119 \\
\hline Tingkat_Keaktifan & Sig. (2-tailed) & .000 & 1 & .008 \\
& N & 119 & .929 & 119 \\
\hline Persepsi_Mahasiswa & Pearson Correlation & .000 & .008 & 19 \\
& Sig. (2-tailed) & .999 & .929 & 119 \\
\hline
\end{tabular}

*Correlation is significant at the 0.01 level (2-tailed)

Berdasarkan tanggapan mahasiswa tentang tingkat kesulitan materi bioteknologi (Gambar 4) dan tanggapan mahasiswa terkait tingkat peguasaan materi bioteknologi yang disampaikan oleh dosen (Gambar 3), menunjukkan bahwa meskipun materi bioteknologi dirasakan sulit oleh mahasiswa, namun dengan penjelasan yang disampaikan oleh dosen pada saat perkuliahan materi bioteknologi dapat dimengerti oleh mahasiswa. Hal ini tidak lepas dari kreatifitas dosen dalam pembelajaran di kelas. Hasil ini didukung oleh tanggapan mahasiswa terkait kreatifitas dosen dalam menyampaikan materi bioteknologi di kelas yang menyatakan materi disampaikan dengan cukup luwes dan fleksibel sebesar 56,3\%, luwes dan fleksibel sebesar $36,1 \%$, mahasiswa yang menjawab biasa saja $6,7 \%$, dan mahasiswa yang menjawab pembelajaran di kelas monoton sebesar $0,8 \%$ (Gambar 5).

Hasil analisis uji korelasi antara tingkat keaktifan mahasiswa dalam mengikuti perkuliahan bioteknologi dengan hasil belajar menunjukkan ada korelasi yang sangat signifikan, dengan nilai korelasi $(r)$ sebesar 0,789 (Tabel 1). Hasil tersebut menunjukkan bahwa faktor 
keaktifan mahasiswa dalam belajar bioteknologi seperti bertanya, mengajukan pendapat, presentasi, dan menyampaikan ide atau pendapat mempengaruhi hasil belajar mereka. Dimana semakin tinggi keaktifan mereka dalam belajar, maka semakin tinggi pula hasil belajar yang diperoleh.

Berdasarkan hasil uji korelasi antara persepsi mahasiswa terhadap hasil belajar bioteknologi, diperoleh nilai $r$ sebesar 0,00 (Tabel 1). Hal ini menunjukkan bahwa tidak ada korelasi antara persepsi mahasiswa yang meliputi perasaan mengikuti perkuliahan bioteknologi, ketertarikan mahasiswa terhadap perkuliahan bioteknologi, penguasaan materi oleh mahasiswa, tingkat kesulitan materi bioteknologi yang disampaikan oleh dosen, dan tanggapan mahasiswa terhadap penyampaian materi oleh dosen terhadap hasil belajar mereka. Hasil ini mengindikasikan meskipun mahasiswa menganggap pembelajaran bioteknologi menarik, menyenangkan, dan mudah dimengeti, namun persepsi tersebut tidak berpengaruh terhadap hasil belajar yang diperoleh.

Meskipun persepsi mahasiswa pada perkuliahan bioteknologi tidak memiliki korelasi secara langsung dengan hasil belajar $(r=0,00)$, namun persepsi mahasiswa menunjukkan minat dan motivasi mahasiwa dalam perkuliahan bioteknologi yang menggambarkan tingkat keaktifan mereka dalam belajar, sehingga mempengaruhi hasil belajar. Sudjana (1989) mengemukakan beberapa prinsip belajar yang mendorong keaktifan mahasiswa dalam belajar, yaitu stimulus belajar, perhatian dan motivasi, respon yang dipelajari, penguatan dan umpan balik.
Pembelajaran

bioteknologi

berusaha untuk membangkitkan motivasi mahasiswa melalui penyampaian yang luwes dan fleksibel, hal ini sesuai dengan besarnya respon mahasiswa terhadap penyampaian materi bioteknologi yang menganggap bahwa materi bioteknologi disampaikan dengan luwes dan fleksibel oleh dosen sebesar 56,30\% (Gambar 5). Hal ini diduga membangkitkan stimulus, motivasi, dan respon mahasiswa dalam belajar bioteknologi yang diperkuat dengan besarnya tanggapan mahasiwa yang menyatakan perkuliahan bioteknologi menyenangkan sebesar $54,60 \%$ (Gambar 1), perkuliahan bioteknologi menarik sebesar $52,90 \%$ (Gambar 2), dan yang menganggap materi bioteknologi mudah dimengerti sebesar $53,80 \%$ (Gambar 3). Oleh karena itu, persepsi mahasiswa menunjukkan besarnya stimulus, motivasi, dan respon mahasiswa dalam belajar bioteknologi yang menggambarkan keaktifan mahasiswa dalam belajar bioteknologi yang pada akhirnya mempengaruhi hasil belajar bioteknologi.

\section{DAFTAR RUJUKAN}

Sanjaya, W. 2006. Strategi pembelajaran Berorientasi Standar Proses Pendidikan. Jakarta: Kencana, Prenada Media Group.

Schielfelbein, E dan Simmons, J. 1981. The Detterminants of School Achievement. Ottawa: IDRC.

Sudjana, N. 1989. Cara Belajar Siswa Aktif. Bandung: Sinar Baru.

Syah, M. 2004. Psikologi Belajar. Jakarta: PT Grafindo Persada 
